\title{
In Spite of Induced Multiple Defense Responses, Tomato Plants Infected with Cucumber mosaic virus and D Satellite RNA Succumb to Systemic Necrosis
}

\author{
Ping Xu, Elison B. Blancaflor, and Marilyn J. Roossinck \\ Plant Biology Division, The Samuel Roberts Noble Foundation, Ardmore, OK 73401 \\ Submitted 17 October 2002. Accepted 23 January 2003.
}

\begin{abstract}
Cucumber mosaic virus (CMV) D satellite RNA (satRNA) attenuates the symptoms induced by CMV in most plants, but causes leaf epinasty and systemic necrosis in tomato plants, where programmed cell death (PCD) is involved. However, our understanding of the cellular and molecular responses to the infection of CMV D satRNA that result in this lethal disease remains limited. In this article, we show for the first time, by histochemical and molecular analysis, that multiple defense responses are specifically induced in CMV and D satRNA (CMV/D satRNA)-infected tomato plants but not in mock-inoculated or CMV-infected plants. These responses include callose deposition and hydrogen peroxide accumulation in infected plants. Furthermore, the transcription of several tomato defense-related genes (e.g., $P R-1 a 1, P R-1 b 1, P R-2$, and $P R-10)$ were activated, and the expression of tomato $P R-5$ and some abiotic and biotic stress-responsive genes (e.g., catalase II and tomato analogs of Arabidopsis AtBI-1 and tobacco hsr203j) are enhanced. The activation and increase in expression of these genes is correlated with the appearance of leaf epinasty and the development of systemic necrosis in infected tomato plants, while increased expression of the $h s r 203 j$ analog precedes the development of any disease symptoms. The spatial and temporal expression patterns of these genes as detected by RNA in situ hybridization point to the involvement of a complex developmental program that accompanies disease development resulting from CMV/D satRNA infection.
\end{abstract}

Cucumber mosaic virus (CMV) is an isometric plant virus with a tripartite plus-sense RNA genome (Palukaitis et al. 1992). CMV satellite RNAs (satRNAs) are small (330 to 405 nt), linear, single-stranded RNAs that are parasites of CMV (García-Arenal and Palukaitis 1999). The CMV satRNAs do not encode any known proteins; hence, all of their biological activity apparently resides in the RNA itself. Although not necessary for the life cycle of CMV, sat RNAs modify CMV symptoms in infected plant hosts. D satRNA is one strain of CMV satRNA that benefits most plant hosts by attenuating the symptoms of CMV. One exception, however, is tomato, where the induction of systemic necrosis causes a lethal disease. This disease has caused catastrophic tomato loss (Grieco et al. 1997; Jordá et al. 1992; Kaper and Tousignant 1977), but no natural resistance has ever been reported. It is known that the $3^{\prime}$ portion of D satRNA is responsible for systemic necrosis (Sleat and Palukaitis 1990; Sleat et al. 1994). A helix and tetraloop

Corresponding author: M. J. Roossinck; Telephone: 580-224-6630; Fax: 580-224-6692; E-mail: mroossinck@noble.org. structure near the $3^{\prime}$ end of the (+)-strand of D satRNA identified by in vitro and in vivo secondary structure analysis is correlated with the necrogenesis of D satRNA (Bernal and GarcíaArenal 1997; Rodríguez-Alvarado and Roossinck 1997). Furthermore, (-)-strand D satRNA apparently was required for tomato lethality (Taliansky et al. 1998), and the accumulation of (-)-strand D satRNA was correlated with the temporal development of systemic necrosis in tomato (Xu and Roossinck 2000). However, the mechanisms involved in symptom expression remain unresolved.

One feature of D satRNA-induced disease development that could have important implications in understanding the cellular basis of disease progression is the involvement of programmed cell death (PCD) (Xu and Roossinck 2000). PCD first was detected in developing phloem cells in tomato stems prior to the onset of visible necrosis. This was followed rapidly by secondary widespread cell death along one side of the stem with ongoing PCD in the phloem cells, which led to the lethal disease and the suicide of both obligate biotrophic viral pathogens and the infected tomato plants. Normally, plants respond to viral pathogenic infection with a compatible reaction showing either disease development or no symptoms or with an incompatible reaction, which is manifested as a hypersensitive response (HR). HR accompanied by localized PCD correlates with the development of plant resistance. Significant progress has been made in characterizing incompatible plant-pathogen interactions that induce plant PCD and disease resistance, wherein plants ward off pathogen infection by eliciting an array of defense mechanisms (Hammond-Kosack and Jones 1996; Lam et al. 2001). There is evidence that virus-induced systemic cell death may result from a gene-for-gene interaction (Király et al. 1999). However, very little is known about nonencoding viral RNA-caused diseases, in spite of extensive genetic analyses of viruses. Based on the increasing data on compatible and incompatible plant-pathogen interactions, we investigated additional responses in tomato plants to the infection of CMV/D satRNA that might play a role in disease development. These included callose deposition, the accumulation of hydrogen peroxide, and the expression of general defense-related genes and some stress-responsive genes.

Callose deposition and rapid accumulation of hydrogen peroxide followed by subsequent cell death are regarded as defense responses against microbial infection (Donofrio and Delaney 2001; Lamb and Dixon 1997). The antifungal activity of tomato PR-1al, PR-1bl, and PR-2 and tobacco native PR-5d was demonstrated (Anfoka and Buchenauer 1997; Niderman et al. 1995), while tobacco PR-5d and one type of PR-10 may have potential antivirus activity (Bantignies et al. 2000; Koiwa et al. 1997; Moiseyev et al. 1994). Some stress-responsive 
genes encode proteins that may play roles in cell protection against abiotic or biotic stresses. For example, tobacco HSR203J, a serine hydrolase, is involved in enhancing defense response and protection against cell death (Baudouin et al. 1997; Tronchet et al. 2001). Catalase detoxifies the effects of hydrogen peroxide (Scandalios 1994). Its expression and activity is correlated with the establishment of hydrogen peroxide mediated-resistance or disease development (Chamnongpol et al. 1998; Du and Klessing 1997; Mittler et al. 1999; Takahashi et al. 1997). The expression of $A t B I$ is up regulated upon microbial challenge and wounding (Sanchez et al. 2000). Over expression of AtBI suppresses Bax-induced plant lethality, suggesting its potential role in retaining the cell viability (KawaiYamada et al. 2001). In this study, Northern blot analyses for these defense- or cell protection-related genes revealed their specific and temporal expression during the onset of CMV/D satRNA-induced disease that was absent in plants infected with CMV alone. RNA in situ hybridization described their spatial expression in the stem tissue of the infected tomato
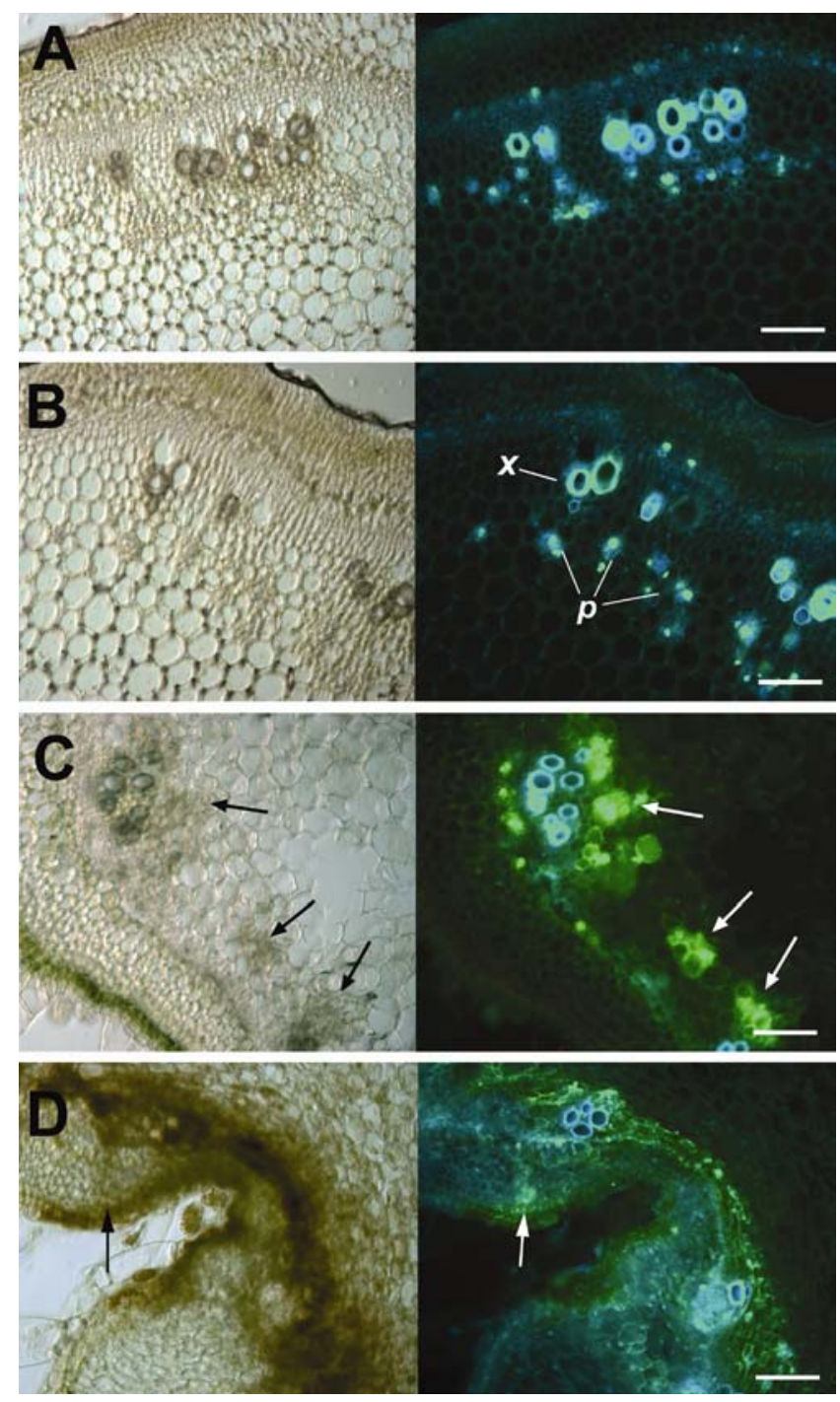

Fig. 1. Callose deposition in infected tomato plants detected by aniline blue staining. A, Mock-inoculated plant at 8 days postinoculation (dpi). B, Fny Cucumber mosaic virus (CMV)-infected plants at $8 \mathrm{dpi}$. C and D, Fny CMV/D satRNA-infected plant at 8 and 9 dpi. Brightfield and corresponding fluorescence images from cross-sections of tomato stems were photographed. The bright green fluorescence that results from UV excitation is indicative of callose accumulation. Arrows in C and D indicate extensive callose accumulation in parenchyma cells surrounding the vascular bundles and cortical cells. Xylem $(x)$, phloem $(p)$. Bar $=50 \mu \mathrm{m}$. plants. The correlation between the defense responses and symptom development during interaction of tomato and CMV/D satRNA is discussed.

\section{RESULTS}

Callose deposition in the cell wall and hydrogen peroxide accumulation in the stem.

Deposition of callose and the generation of hydrogen peroxide have been well established as part of the defense response of plants to microbial infection (Lamb and Dixon 1997; Sticher et al. 1997). To determine whether tomato plants infected with CMV/D sat RNA display similar defense responses, we assayed for callose and hydrogen peroxide accumulation. Callose was detected by staining tomato cross-sections with aniline blue. Aniline blue binds to 1,3- $\beta$ glucose residues and emits a bright yellowish to green fluorescence upon excitation with UV light that is detectable with fluorescence microscopy (Smith and McCully 1978). Hydrogen peroxide was visualized by treating infected stems with 3,3'-diaminobenzidine (DAB). $\mathrm{DAB}$ is oxidized in the presence of hydrogen peroxide, producing a visible red precipitate (Thordal-Christensen et al. 1997).

In both mock- (Fig. 1A) and Fny CMV- (Fig. 1B) inoculated plants, a trace amount of callose was detected within the vascular elements (e.g., xylem and phloem). This is an expected result because callose typically is associated with the walls of vascular cells where it functions in reinforcing wall structure (Smith and McCully 1978). In CMV/D sat RNA-infected plants, however, callose accumulated to significantly higher levels as evident from the intense bright green fluorescence observed in tomato cross-sections (Fig. 1C and D). Although callose was particularly enriched in the phloem and xylem elements, extensive accumulation also was observed in the walls of vascular parenchyma cells at the prenecrotic stage (8 days postinoculation [dpi]) (Fig. 1C). In severely necrotic tissues, deposition of callose spread to the outer cortex and portions of the epidermis (Fig. 1D).

Hydrogen peroxide displayed a pattern of induction similar to callose in response to CMV/Dsat RNA inoculation. Tomato plants inoculated with CMV/D sat RNA displayed extensive formation of the red precipitate resulting from the hydrogen peroxide-DAB reaction along one side of the stem during the development of systemic necrosis, whereas no accumulation of hydrogen peroxide was found in the stem of mock- or Fny CMV-inoculated tomato plants (Fig. 2). A trace amount of red precipitate also was generated in some developing vascular bundles in all the inoculated plants (data not shown).

\section{Expression of $P R$ genes \\ in CMV/D satRNA infected-tomato plants.}

The expression of $P R$ genes in tomato plants was analyzed by Northern blot analysis. One group of plants was inoculated at the three-leaf stage. The plants inoculated with CMV/D satRNA developed leaf epinastic symptoms at approximately $7 \mathrm{dpi}$, and the systemic necrosis was first visible at approximately 9 dpi and became more apparent at 10 to 11 dpi (Fig. 3A to D). Total RNA was extracted from the apical tissues of the inoculated plants, including the second node below the meristem, at various dpi, and expression patterns were assessed by Northern blot (Fig. 3E). The cDNA sequences of tomato $P R-1 a 1, P R-1 b 1$, and $P R-2$ used to generate probes are identical to those in previously published reports (Tornero et al. 1993, 1994, 1997; vanKan et al. 1992). The cDNA sequence of tomato $P R-5$ shares approximately $92 \%$ identity with the tobacco $P R-5 d$ (Takeda et al. 1991). The cDNA sequence of tomato $P R-10$ shares $82 \%$ identity with potato sth-2 (Matton and Brisson 1989). All tested $P R$ 
genes except $P R-5$ were expressed specifically in CMV/D satRNA-infected tomato plants at $7 \mathrm{dpi}$, and the expression increased to a higher level at 9 dpi (Fig. 3E). $P R-5$ was expressed constitutively in all the inoculated tomato plants, but the expression in the CMV/D satRNA-infected plants began to increase at $7 \mathrm{dpi}$ and reached a high level by 9 dpi. Another $P R-5$ family member with a size of approximately 1.8 $\mathrm{kb}$ is expressed specifically in the necrotic tomato plants (Fig. 3E). Total RNA also was extracted from the necrotic leaves and the stems without necrosis below the second node at $9 \mathrm{dpi}$, and from the apical tissues with severe necrosis at 11 dpi. No significant difference was seen in the expression level of $P R$-lal among these tissues. The transcript levels of $P R-2, P R-5$, and $P R-10$ were reduced in severely necrotic tissues at 11 dpi. More $P R-5$ mRNA was expressed in the stem below the second node without visible necrosis, whereas less $P R-10$ was expressed.

A second group of plants was inoculated at the two-leaf stage. The plants inoculated with CMV/D satRNA developed the epinastic leaf symptoms at approximately $5 \mathrm{dpi}$, the symptoms became more severe at approximately $7 \mathrm{dpi}$, and systemic necrosis developed at approximately 8 to 9 dpi (Fig. $4 \mathrm{~A}$ to D). Total RNA was extracted from the apical part of these plants, and the Northern blot was probed with $P R-1 b 1$. The result showed that the $P R-1 b 1$ gene was expressed at a low level in CMV/D satRNA-infected tomato plants at $5 \mathrm{dpi}$, and the expression increased to a high level at 9 dpi (Fig. 4E).

\section{Expression of tomato catalase II gene and tomato analogs} of Arabidopsis AtBI-1 and tobacco $h s r 203 j$ in tomato plants.

Total RNA from the second group of plants was used for northern blot analysis with the probes from catalase II gene (cat II), tomato analogs of Arabidopsis AtBI-1 (tomBI-1), and tobacco $h s r 203 j$ (tomhsr203j) cDNAs. The cDNA sequence of cat II used to generate the probe shares $99 \%$ identity with a tomato catalase from GenBank (M93719) and 96\% identity with a potato catalase II gene, Cat2St (Wu and Shah 1995). The sequence of tomBI- 1 is approximately $76 \%$ identical to AtBI-1 (Bax-inhibitor), and the encoded protein shares $89 \%$ similarity (Sanchez et al. 2000). The cDNA clone sequence of tomhsr $203 j$ shares $85 \%$ identity to tobacco $h s r 203 j$ (serine hydrolase), and the encoded protein shares $93 \%$ similarity (Pontier et al. 1994). The Northern blot analysis showed that these three genes were expressed constitutively in all the inoculated plants at low levels. The expression of cat II started to increase at $5 \mathrm{dpi}$ when the epinastic leaf symptoms were developing in CMV/D satRNA-infected tomato plants, and reached a high level in epinastic and necrotic tomato plants at 7 and 9 dpi (Fig. 4E). An increase of tomBI-1 was detected in CMV/D satRNA-infected tomato plants with severe epinastic leaf symptoms at $7 \mathrm{dpi}$, and stayed at a relatively high level in the necrotic tomato plants at 9 dpi (Fig. 4E). The expression of tomhsr203j showed a slight increase in CMV-infected tomato plants, but a larger increase was detected in CMV/D satRNA-infected tomato plants beginning at $3 \mathrm{dpi}$, preceding all the visible symptoms. The level reached a peak in the plants with severe epinastic leaf symptoms at 7 dpi (Fig. 4).

\section{Spatial expression}

of $P R-1 b 1, P R-10$, and $t o m B I-1$ in the necrotic stems.

RNA in situ hybridization of infected stem sections was performed with $P R-1 a 1, P R-1 b 1$, and $P R-10$ antisense RNAs labeled with digoxygenin, which yields a purple color (Figs. 5 to 7). The $P R-1 b 1$ gene was expressed in most of the cell types in necrotic tomato stems (Fig. 5C). Stronger signals were seen in epidermal cells, phloem and vascular parenchyma cells, and adjacent pith cells (Fig. 5D and E). Spatially, the distribution of $P R-1$ mRNA was not correlated with the cell death pattern in the stem. No signal was detected in the mock- or Fny CMVinoculated plants (Fig. 5A and B) or the dead cells in the CMV/D satRNA-infected plants (Fig. 5E). PR-lal showed an expression pattern similar to $P R-1 b l$ (data not shown). No expression of $P R-10$ was detected in the mock- or Fny CMVinoculated plants (Fig. 6A and B). In CMV/D satRNA-infected tomato plants at the necrotic stage, $P R-10$ was expressed specifically in some vascular parenchyma cells (Fig. 6C, E, and G). RNA in situ hybridization for satRNA localization was done with serial sections of the same tissue. Compared with the localization of D satRNA in the stem, the expression of $P R-10$ was associated with some infected vascular parenchyma cells around the vascular elements or adjacent to the necrotic cells (Fig. 6E to H). TomBI-1 was constitutively expressed in the epidermal and phloem cells in mock- or CMV-inoculated tomato plants at a low level (Fig. 7A to D). In necrotic tomato stems infected with CMV/D satRNA, the expression was detected in most of the cell types (Fig. 7E, G, and J), whereas the highly enhanced expression was specific to epidermal and vascular cells. The increased expression was associated with the D satRNA-infected cells localized in the serial sections along the collapsed cells or infected phloem cells and the parenchyma cells around the vascular elements (Fig. 7F, G, I, and $\mathrm{J}$ ).
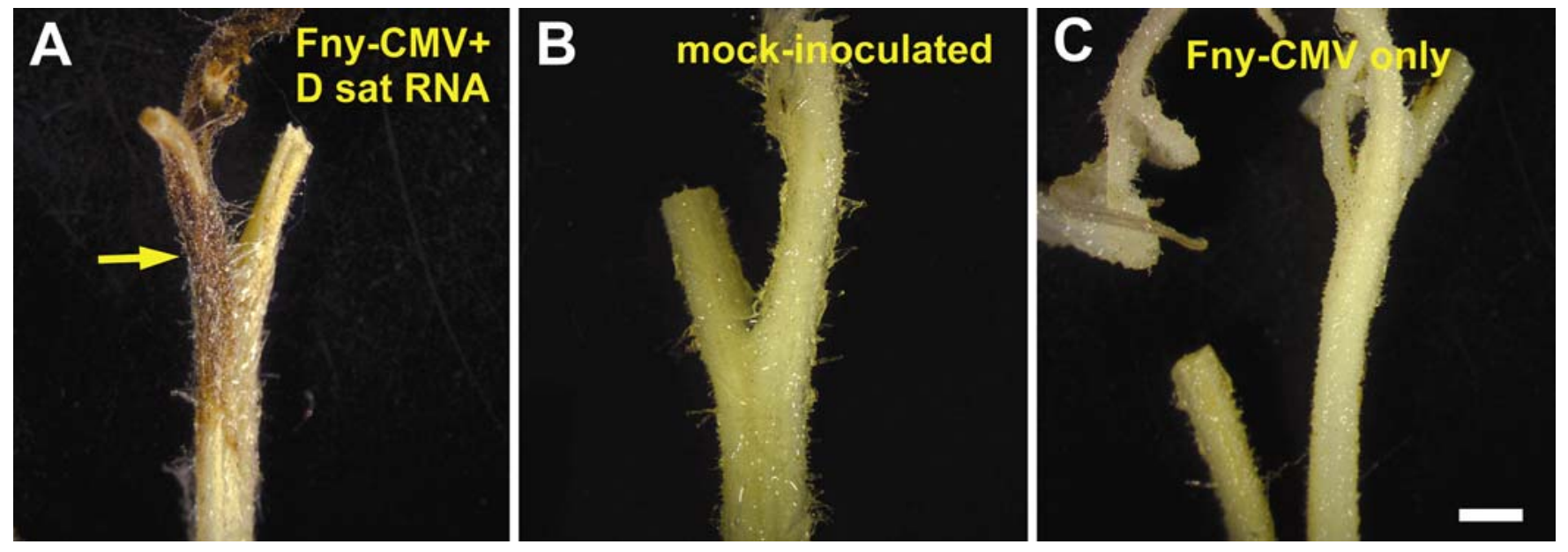

Fig. 2. Hydrogen peroxide accumulation in tomato stems detected by 3, 3'-diaminobenzidine (DAB). The formation of red precipitate is indicative of hydrogen peroxide formation (arrow). A, Cucumber mosaic virus (CMV)/D satellite RNA-infected plant; B, mock-inoculated plant; C, Fny CMV-infected plant. Bar $=1 \mathrm{~mm}$. 


\section{DISCUSSION}

On the basis of its wide host range and worldwide distribution, CMV is one of the most evolutionarily successful viruses known. CMV can harbor satRNAs, which usually behave more like mutualists of their plant hosts, reducing symptoms and virus titer. The D satRNA in tomato plants is an exception, causing a lethal disease that eventually destroys the helper virus CMV, tomato plants, and D satRNA itself. In addition to the tomato cell death induced by the infection of CMV/D satRNA, the results from the specific or enhanced expression of defense-related $P R$ genes and cell protection-related genes, callose deposition, and accumulation of hydrogen peroxide show that multiple defense responses also are induced and correlate with the development of disease symptoms that do not occur with virus infection alone.
The accumulation of PR proteins has been associated with the onset of local or systemic cell death in some plant-pathogen interactions (Cai et al. 2001; Cole et al. 2001; vanKan et al. 1992; vanLoon 1999). The transcription of PR-1al also was correlated with the manifestation of symptoms like leaf epinasty and rugosity in viroid-infected tomato plants (Tornero et al. 1994), but none or only small amounts of PR proteins were induced in virus-infected plants with chlorotic or mosaic-type symptoms (vanLoon 1999). Similar results are observed in our work. The transcription of all the tested tomato PR genes were activated or enhanced in the apical part of the CMV/D satRNA-infected tomato plants with leaf epinasty and necrosis symptoms, but not in CMV-infected plants with shoestring leaf and mosaic symptoms. It is likely that either the signals that elicit the induction of these PR proteins are produced during the development of leaf epinasty and cell death caused by CMV/D satRNA infection, or the signals that
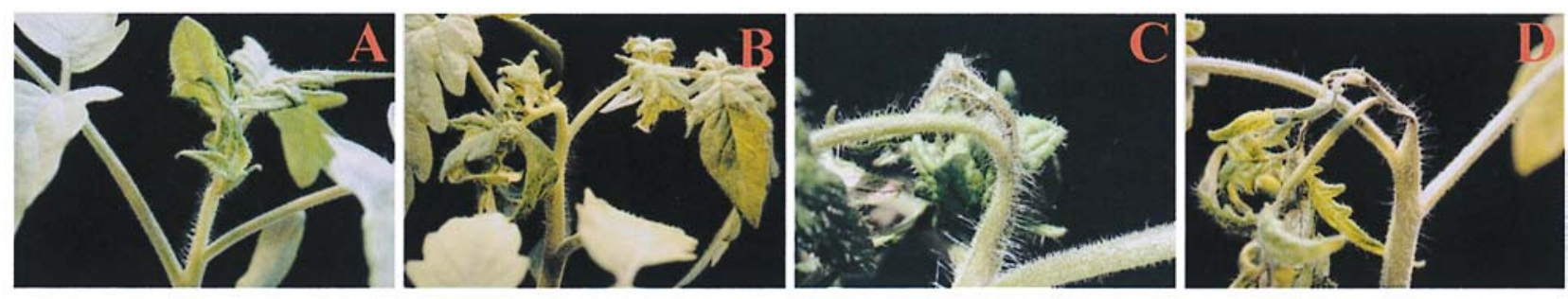

$\mathbf{E}$

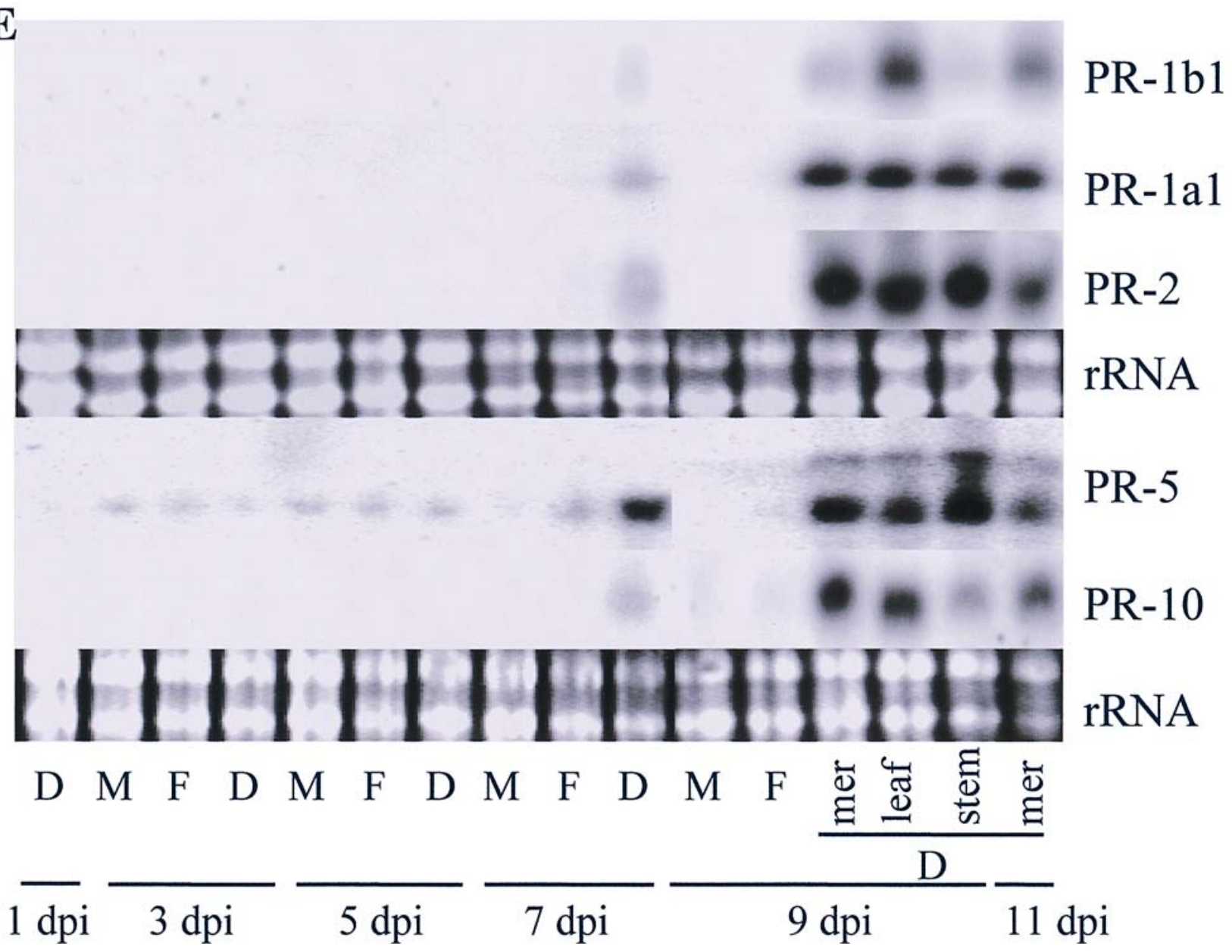

Fig. 3. A through D, Temporal development of the symptoms in a tomato plant infected with Cucumber mosaic virus (CMV)/D satellite RNA (satRNA) at the three-leaf stage and E, Northern blot analysis of the temporal expression of $P R-1 a 1, P R-1 b 1, P R-2$ (GLU), $P R-5$, and $P R-10$ genes in the inoculated tomato plants. A, Plant at 5 days postinoculation (dpi) showing no symptoms; B, plant at 7 dpi showing leaf epinasty; C, plant at 9 dpi showing mild systemic necrosis in the stem; D, plant at 11 dpi showing severe systemic necrosis. E, M, F, and D stand for the total RNA from mock-, Fny CMV-, and Fny CMV/D satRNA-inoculated tomato plants, respectively; mer, from apical (meristematic) tissue; leaf, necrotic leaf tissues; stem, stem tissue below the second node, without necrosis; rRNA, 28s rRNA, and 18s rRNA bands after EtBr staining. 
induce the symptom development are produced during the activation of PR genes.

One possible signal molecule is hydrogen peroxide. Its role in activating plant defense responses, including PR protein synthesis, is well known (Lamb and Dixon 1997; OrozcoCárdenas et al. 2001), while it is also suggested as a key factor mediating PCD in response to pathogens, elicitors, and hormones (Bethke and Jones 2001; Jabs 1999; Karpinski et al. 1999; Lamb and Dixon 1997). In this work, the accumulation of hydrogen peroxide was detected along the side of the stem where systemic cell death would develop in CMV/D satRNAinfected tomato plants. Moreover, the transcription of PR genes was dramatically increased. These observations indicate that hydrogen peroxide may play dual roles in up regulating the expression of $P R$ genes and mediating systemic necrosis during stress acclimation. In the meantime, a marked increase in the expression of tomato cat II temporally was correlated with accumulation of hydrogen peroxide in the stem, implicating the activation of self-protection responses during the development of disease symptoms. This also can be deduced from the expression increase of tomBI-1 and tomhsr203j in CMV/D
satRNA-infected tomato plants. A slight expression increase of tomhsr203j was detected in CMV-infected tomato plants, whereas a larger increase was seen in CMV/D satRNAinfected plants at $3 \mathrm{dpi}$. No visible disease symptoms were seen at that time, indicating that the infection stress had been sensed far before the visible symptoms and that the physiological difference caused by the infection of CMV and CMV/D satRNA occurred at an early stage of infection.

The expression of the $P R$ genes and tomBI- 1 was correlated temporally with the development of the CMV/D satRNAcaused disease symptoms, but their spatial expression patterns and relations with cell death or the infection of D satRNA were different, indicating they were under different and complex regulation. In addition, their expression patterns also were different from other biotic stresses. In the systemically infected tomato plants with CMV/D satRNA, no direct spatial correlation was detected between the cell death region and the spatial expression of $P R-1 b l$. However, in tomato plants infected with Tobacco mosaic virus, $P R-1 b 1$ is strongly expressed around the infection site and at a greater distance from the lesion but not in the systemic leaves (Tornero et al. 1997). Therefore, the
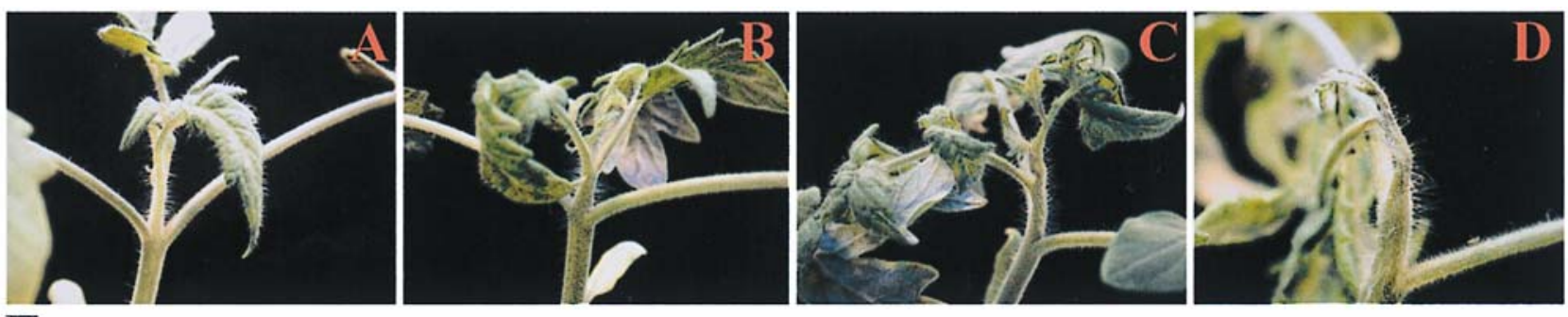

E

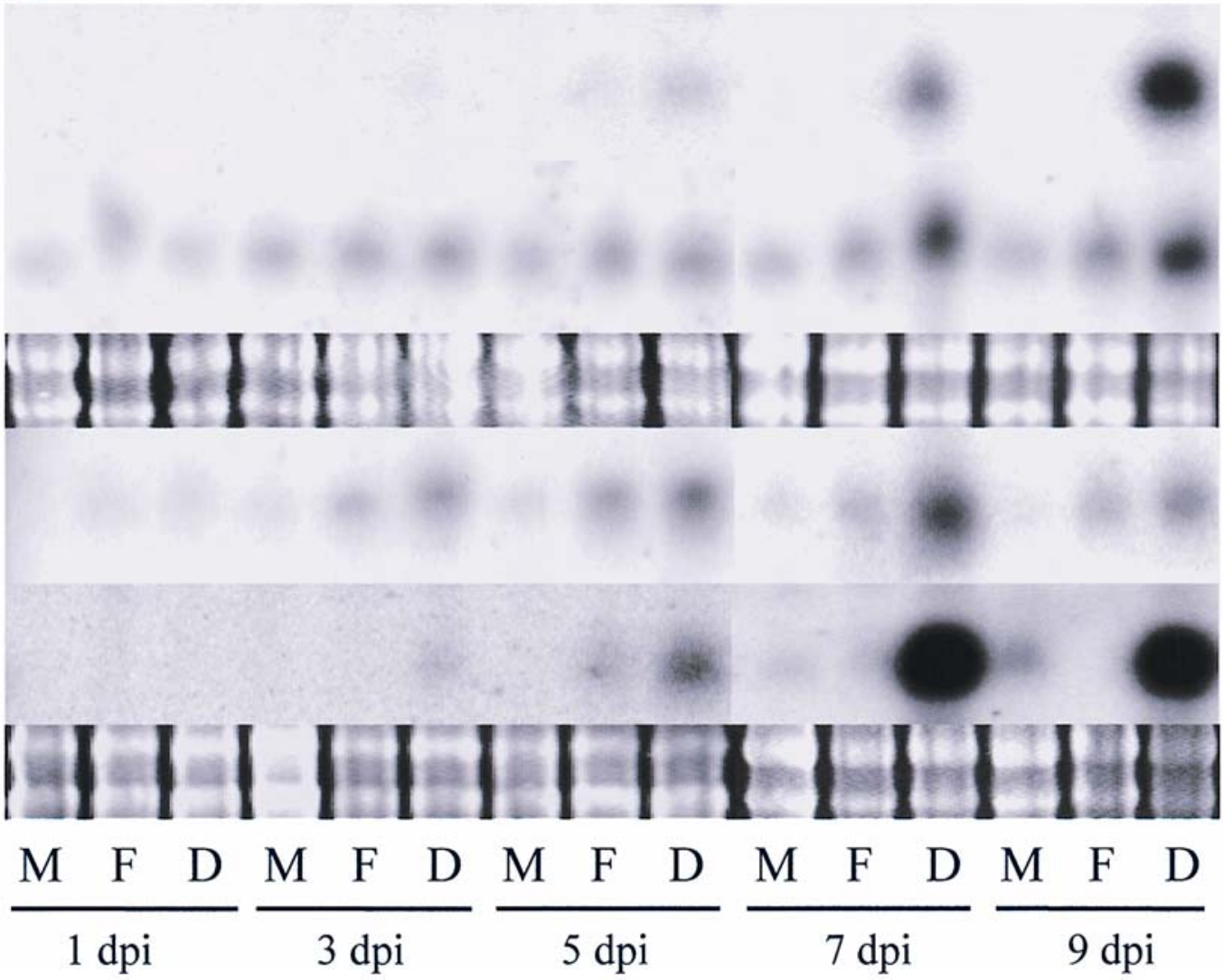

PR-1b1

tomBI-1

\author{
rRNA
}

\section{tomhsr $203 \mathrm{j}$}

cat II

rRNA

Fig. 4. A through D, Temporal development of the symptoms in a tomato plant infected with Cucumber mosaic virus (CMV)/D satellite RNA (satRNA) at the two-leaf stage and $\mathbf{E}$, Northern blot analysis of the temporal expression of PR-1b1, tomBI-1, tomhsr $203 j$, and cat II in the tomato plants. A, Plant at 3 days postinoculation (dpi) showing no symptom; B, plant at 5 dpi showing leaf epinasty; C, plant at 7 dpi showing severe epinastic leaves; D, plant at 9 dpi showing systemic necrosis. E, M, F, and D stand for total RNA from mock-, Fny CMV-, and Fny CMV/D satRNA-inoculated tomato plants, respectively; rRNA, 28S rRNA, and 18S rRNA bands after EtBr staining. 
mechanisms involved in the induction of defense response and cell death caused by these two viruses are different. The spatial expression of $P R-10$ in plants varies in different hosts in response to different pathogens as well. In some cases, the transcript has been localized to the regions of wounding or fungal inoculation and adjacent areas (McGee et al. 2001; Schmelzer et al. 1989; Warner et al. 1993), but the vascular-specific expression pattern of potato sth-2 and of an alfalfa $P R-10$ was detected in response to both abiotic and biotic stresses (Breda et al. 1996; Constabel and Brisson 1995). Potato sth-2 also was expressed in a stigma-specific fashion during normal reproductive development (Constabel and Brisson 1995). Here, the tomato homologue of potato sth-2 showed a vascular parenchyma cell-specific expression pattern in the stem in response to CMV/D satRNA infection. The expression also was found in the leaf primordium of CMV/D satRNA-infected tomato plants (data not shown). These implicate a complicated involvement of developmental regulation and specific infection stress from D satRNA.

The spatial expression of plant $B I-1$ was not reported previously. Our work shows that tomBI- 1 is expressed constitutively in the epidermal and phloem cells at a low level. This specialized expression pattern of tomBI-1 in the stem changes upon the infection of CMV/D satRNA when systemic necrosis is developing. The expression is not limited to epidermal and phloem cells but also occurs in other cell types, such as the pa- renchyma cells, indicating a cross-talk of developmental and stress-responsive regulation. A dramatic increase of expression is detected in severely infected phloem cells and vascular parenchyma cells or the vascular parenchyma cells neighboring the necrotic cells. Based on previous work, the cell death program is initiated in these cells (Xu and Roossinck 2000), suggesting the coexistence of PCD and defense responses to the infection of CMV/D satRNA in the same cells.

Although multiple defense and cell protection responses against tissue damage were systemically induced, tomato plants infected with CMV/D satRNA still succumbed to systemic necrosis. It is possible that D satRNA usually benefits its plant host with induced defense responses but causes an accidental systemic necrosis in tomato. The signal transduction pathways leading to defense responses and symptom development induced by D satRNA infection are separate but with cross-talk such as the accumulation of hydrogen peroxide. It is noteworthy that the activation of PR gene transcription precedes the accumulation of hydrogen peroxide and systemic cell death, indicating that another signal or signals induced by the stress of D satRNA infection leads to the activation of PR genes, production of hydrogen peroxide, and the initial symptoms, while the accumulation of hydrogen peroxide exacerbates the physiological responses. Furthermore, in other studies, increased expression of $P R-2,1,3-\beta$ gluconase (GLU) gene, in virus-infected cells increased the size of local lesions

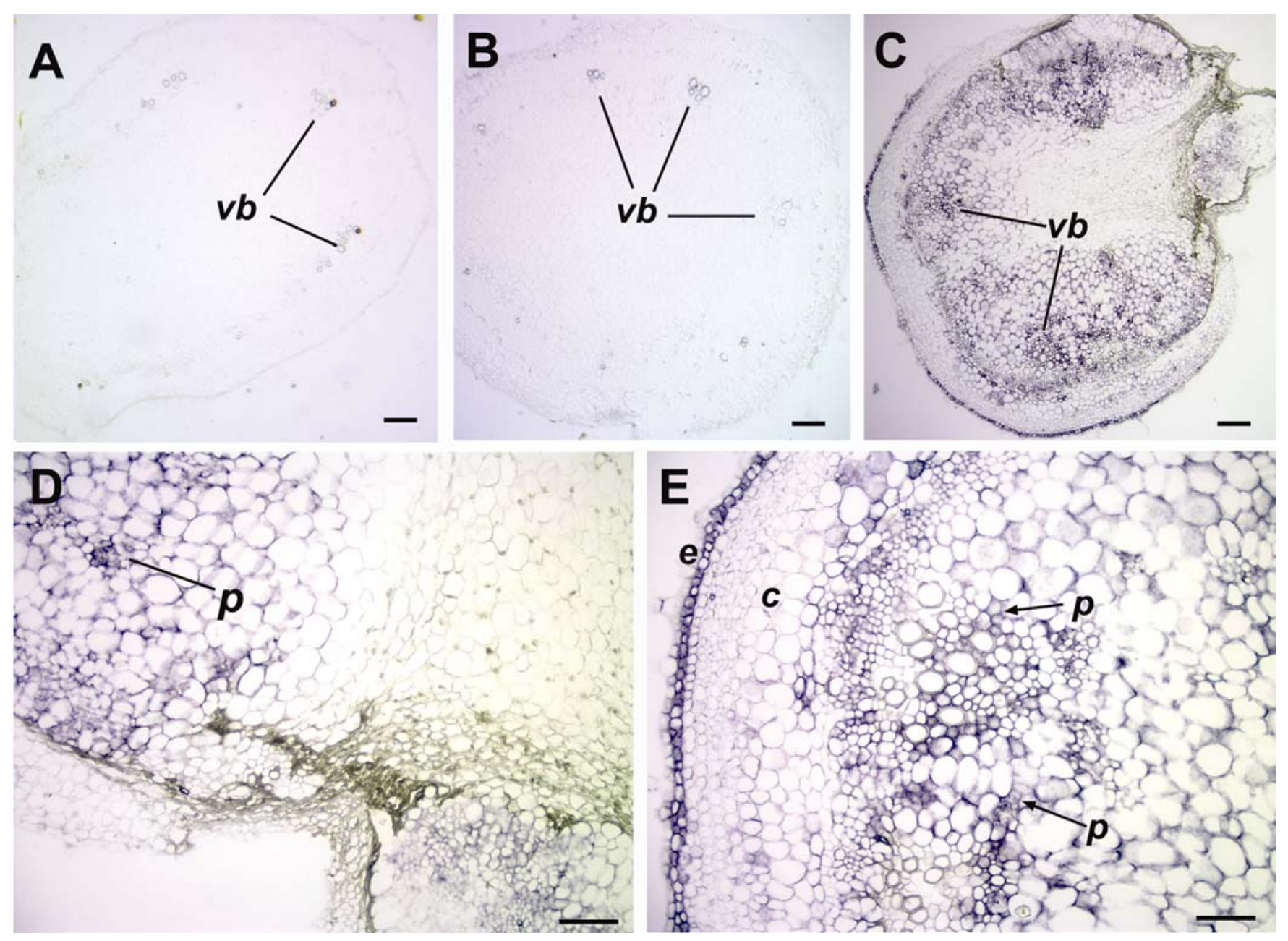

Fig. 5. RNA in situ hybridization showing the localization of $P R-1 b 1$ transcript in cross-sections of tomato stems. A, Mock-inoculated plant. B, Fny Cucumber mosaic virus (CMV)-infected plant. C, Fny CMV/D satellite RNA-infected plant. D, Magnified image of a region from the necrotic side of the section in $\mathrm{C}$ showing high expression of $P R-1 b 1$ in the phloem cells as well as surrounding vascular parenchyma cells. E, Magnified portion of the nonnecrotic side of the section in $\mathbf{C}$ indicating high expression of $P R-1 b 1$ in vascular parenchyma and epidermal cells (arrows). Epidermis $(e)$, phloem $(p)$, cortex $(c)$, vascular bundles $(v b)$. Bars $=100 \mu \mathrm{m}$. 
and promoted virus spread (Bucher et al. 2001). Tobacco deficient in GLU by antisense suppression exhibited delayed spread of Tobacco mosaic virus and a recombinant Potato virus $X$ (Iglesias and Meins 2000). Here, the expression of $P R$ 2 was seen before the occurrence of necrosis or obvious callose deposition. The defense response of callose deposition induced by D satRNA infection may occur too late to limit virus spread.

In conclusion, multiple defense responses associated with the development of disease symptoms were induced in CMV/D satRNA but not in CMV-infected tomato plants while cell protection responses, probably against tissue damage caused by biotic stress, also occurred after inoculation. The final expression of the disease symptoms, including leaf epinasty and systemic necrosis from the widespread PCD, must be the result of the comprehensive interaction of tomato developmental regulation and the multiple responses to the infection of this small satRNA. How a noncoding RNA interacts with its host and helper virus to induce this cascade of events remains to be elucidated.

\section{MATERIALS AND METHODS}

\section{Plant material and treatments.}

Virus and viral RNA was purified from tobacco plants (Nicotiana tabacum, cv. Xanthi nc) inoculated with Fny CMV transcripts from cDNA clones and Zucchini squash plants $(\mathrm{Cu}$ curbita pepo cv. Elite) inoculated with Fny CMV and D satRNA transcripts as previously described (Roossinck and White 1998; Xu and Roossinck 2000). Tomato (Lycopersicon esculentum cv. Rutgers) seedlings used for inoculation were grown to the two- or three-leaf stage under greenhouse condi- tions, and inoculated with viral RNAs as previously described (Xu and Roossinck 2000).

The EST cDNA clones of PR-1al (cLET29G19), $P R-1 b 1$ (cLER8E8), $P R-2$ (GLU) (cLES4I4), $P R-5$ (cLER11F1), $P R$ 10 (cLEC7D22), tomBI-1 (cLES7M13), and tomhsr203j (cLES6F9) were purchased from the Genomics Institute of Clemson University. The EST clone of tomato cat II was a gift from A. Itaya (Oklahoma State University). The cDNA clone pDsat4SK was used for synthesis of minus-sense D satRNA synthesis (Xu and Roossinck 2000).

\section{Detection of callose and hydrogen peroxide.}

The first leaves of tomato seedlings at the two- or three-leaf stage were inoculated with inoculation buffer $(50 \mathrm{mM}$ $\mathrm{Na}_{2} \mathrm{HPO}_{4}, \mathrm{pH}$ 9.2) and Fny-CMV RNAs or Fny CMV RNAs + D satRNA at a concentration of $500 \mu \mathrm{g} / \mathrm{ml}$. Stems around the second node from the three groups of inoculated plants were harvested at different dpi and 50 to $100 \mu \mathrm{m}$ of stem crosssections were obtained using a Vibratome 1000 (Technical Products International, St. Louis). The sections were transferred to glass slides and incubated in aniline blue solution $\left(0.01 \%\right.$ in $\left.1.5 \% \mathrm{~K}_{2} \mathrm{PO}_{4} \mathrm{H}, \mathrm{pH} 8.6\right)$ for $10 \mathrm{~min}$, washed with $\mathrm{K}_{2} \mathrm{PO}_{4} \mathrm{H}$ for $5 \mathrm{~min}$, and examined under a Nikon Microphot upright fluorescence microscope using UV filters sets $(365 \mathrm{~nm}$ excitation, 400 emission, 390 dichroic). Images were collected using a Leica DC200 digital camera.

For hydrogen peroxide detection, tomato plants inoculated at the three-leaf stage were cut at different dpi and their leaves gently trimmed off. The stems then were dipped into a solution of DAB $(\mathrm{pH} 3.8,10 \mu \mathrm{g} / \mathrm{ml})$ and incubated at room temperature for $8 \mathrm{~h}$. After DAB incubation, the stems were dehydrated in

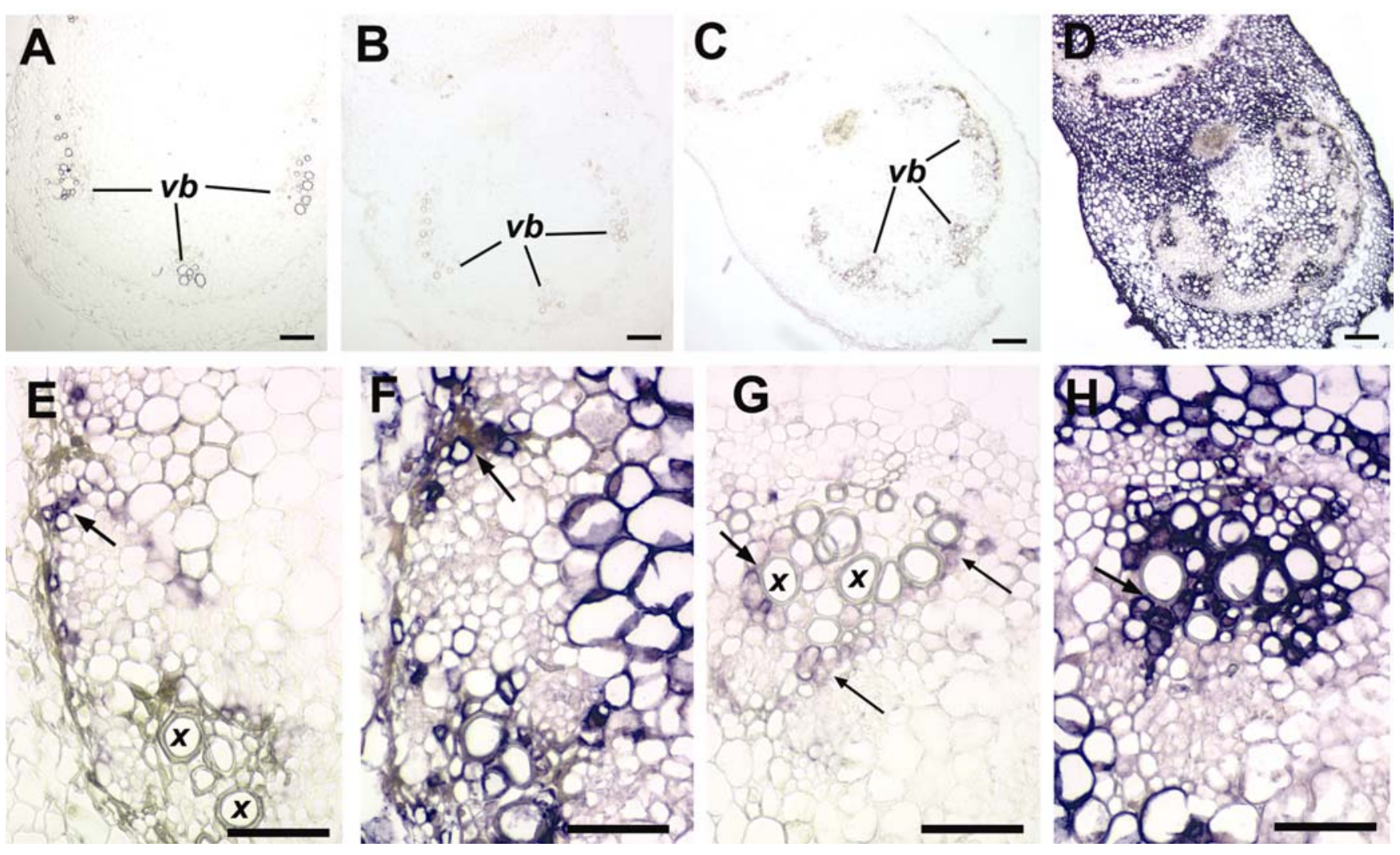

Fig. 6. RNA in situ hybridization showing the localization of $P R-10$ transcript and D satellite RNA (satRNA) in serial stem sections of Cucumber mosaic virus (CMV)/D satRNA-infected tomato plant at 9 days postinoculation. A, Mock-inoculated plant. B, Fny CMV-infected plant. C and D, CMV/D satRNA-infected plant. $\mathbf{E}$ through $\mathbf{H}$, Magnified images of the necrotic and nonnecrotic sides, respectively, of the sections in C and D showing $P R-10$ transcripts in the vascular parenchyma cells neighboring the cells undergoing necrosis (arrow in E) and the parenchyma cells within the immediate vicinity of the vascular elements (arrows in G). A, B, C, E, and G are probed for PR-10; D, F, and $\mathrm{H}$ are probed for D sat RNA. Xylem $(x)$. Bars $=1 \mathrm{~mm}(\mathrm{~A}$ through D) or $50 \mu \mathrm{m}(\mathrm{E}$ through $\mathrm{H})$. 
boiling 95\% ethanol and the formation of a red precipitate was observed. The stems were photographed with a SPOT RT digital camera (Diagnostic Instruments, Sterling Heights, MI, U.S.A.) connected to an Olympus SZX12 dissecting microscope.

\section{Northern blot analysis.}

The pictures of the apical part of inoculated tomato plants were taken with a COOLPX990 digital camera (Nikon, Melville, NY, U.S.A.). Approximately 0.2 to $0.4 \mathrm{~g}$ of apical tissues from plants inoculated at the two-leaf stage were harvested at $1,3,5,7$, and 9 dpi and rapidly frozen in liquid nitrogen. Similar amounts of tissue from the tomato plants inoculated at the three-leaf stage were harvested at $1,3,5,7,9$, and $11 \mathrm{dpi}$. The necrotic leaves from tomato plants inoculated with CMV/D satRNA at 9 dpi and the stems below the second node without visible necrosis also were harvested. The total RNA was extracted from these tissues with the protocol for Tri-reagent (Molecular Research Center, Inc, Cincinnati, OH, U.S.A.). The concentrations of RNA samples were determined by UV absorption at $260 \mathrm{~nm}$ (A260). Approximately $50 \mu \mathrm{g}$ of total RNA from each sample was used for Northern blot analysis. The RNA samples were denatured with the protocol for Hybond $\mathrm{N}+$ membrane (Amersham Bioscience, Piscataway, NJ, U.S.A.), and loaded on a $1.5 \%$ agarose gel in Tris-borateEDTA. After electrophoresis, the gels were stained with $0.01 \%$ (wt/vol) EtBr and visualized with a UVP Bioimaging System. The RNA samples in the gels were transferred to Hybond N+ membrane overnight by the capillary method and baked in a vacuum oven at $80^{\circ} \mathrm{C}$ for $3 \mathrm{~h}$.

The purchased cDNA clones were analyzed by sequence determination on an Applied Biosystems sequencer, 3100 Genetic Analyzer (Hitachi, Foster City, CA, U.S.A.) to confirm their identities. The cDNA inserts were released from the plasmids by digestion with EcoRI and XhoI, and purified from an agarose gel with a QIAquick gel extraction kit (Qiagen Inc., Valencia, CA, U.S.A.). The DNA probes were labeled with $\alpha$ -

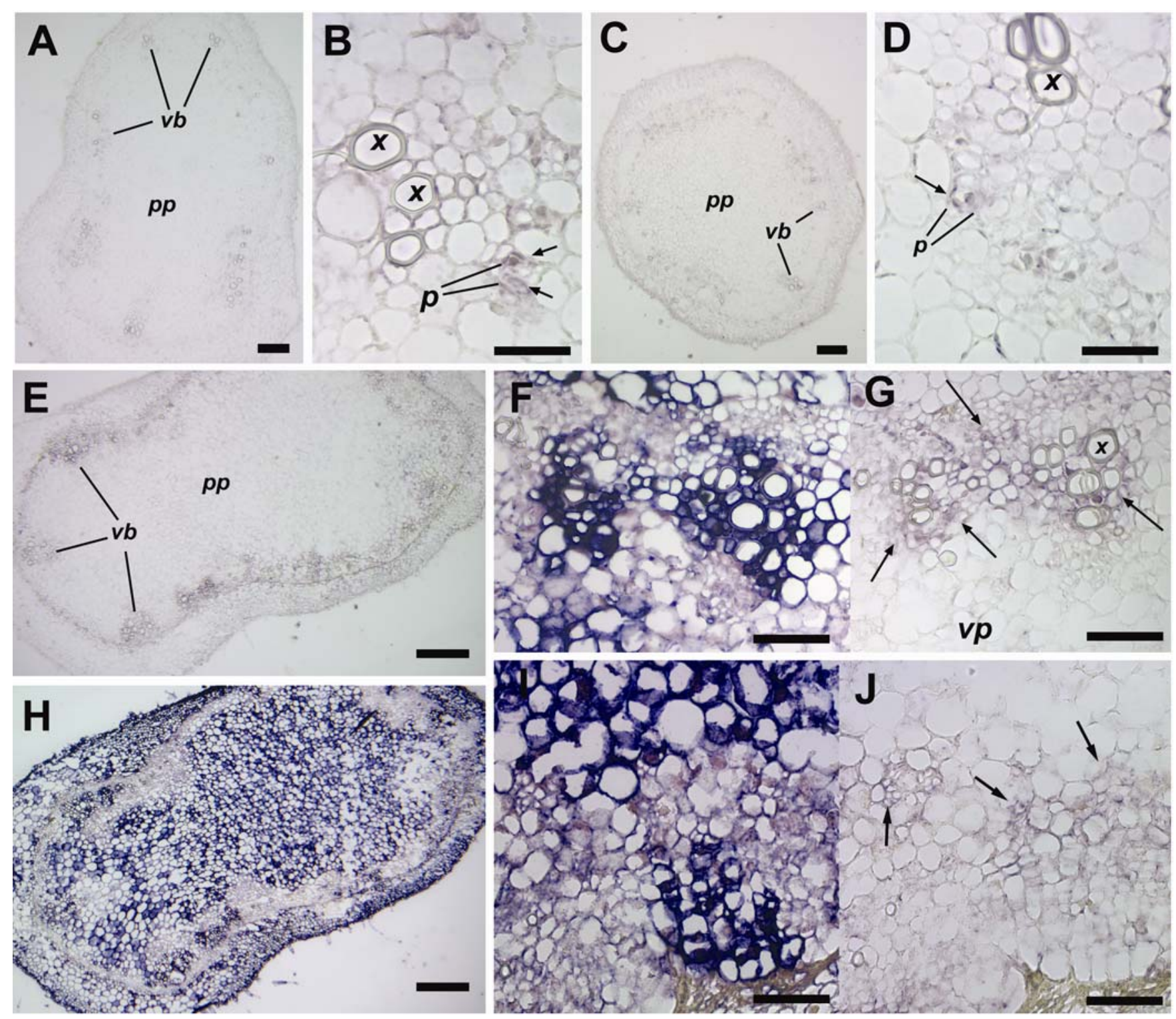

Fig. 7. RNA in situ hybridization showing the localization of tomBI-1 transcripts and D satellite RNA (satRNA) in serial stem sections. A, Cross section from mock-inoculated plant; C, from Fny Cucumber mosaic virus (CMV)-infected plant; B and D, magnified portions from A and C showing low expression of tomBI-1 in the phloem cells (arrows). $\mathbf{E}$ and $\mathbf{H}$, Serial cross-sections from CMV/D sat RNA-infected plant. F and $\mathbf{G}$, Magnified images from the nonnecrotic side of the sections in E and $\mathrm{H}$; I, and J, magnified images from the necrotic side of the sections in E and $\mathrm{H}$. F, $\mathbf{H}$, and I, Cross-section labeled with D satRNA probe; $\mathbf{E}, \mathbf{G}$, and $\mathbf{J}$, cross-section labeled with the tomBI-1 transcript probe. Arrows indicate the highest level of expression was observed in parenchyma cells around the vascular elements. Vascular parenchyma cell $(v p)$, pith cells $(p p)$. Bars $=50 \mu \mathrm{m}$. 
$\mathrm{P}^{32}$-dCTP by random priming with Ready-to-go DNA Labeling Beads (Amersham and Pharmacia Biotech, Inc.). The Church method was used for Northern blot hybridization (Church and Gilbert 1984). The hybridized and washed membranes were exposed to a Phosphorimager cassette and scanned (Molecular Dynamics, Sunnyvale, CA, U.S.A.). Membranes were stripped by incubation in $0.1 \%$ sodium dodecyl sulfate for $3 \mathrm{~h}$ at $80^{\circ} \mathrm{C}$. Each membrane was hybridized three times with different probes.

\section{RNA in situ hybridization.}

The truncated 3 '-end sequences of $P R-1 a 1, P R-1 b 1, P R$ 10 , and tomBI-1 cDNAs were subcloned into pBlueScript $\mathrm{KS}+$ vector (Stratagene, La Jolla, CA, U.S.A.). TomBI-1 and $P R$-lal plasmids were digested with HindIII and $X b a \mathrm{I}$, and the released DNA fragments were ligated with HindIII and $X b a \mathrm{I}$ digested pBluescript $\mathrm{KS}+$ vector with $\mathrm{T}_{4}$ DNA ligase (Promega Corp., Madison, WI, U.S.A.). The subclones of

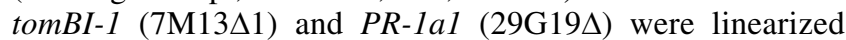
with $X b a I$ or HindIII and used to generate the sense and antisense RNAs labeled with deoxygenin-UTP. The plasmid containing $P R-10$ was digested with HindIII, and the released DNA fragment was cloned into pBlueScript $\mathrm{KS}+$ vector. The subclones were sequenced and two plasmids with sense or anti-sense cDNA sequence (7D22 $\Delta 1$ and 7D22 $\Delta 2$ ) were used for the synthesis of sense and anti-sense RNA probes labeled with deoxygenin-UTP. An oligo DNA primer was synthesized for subcloning $P R-1 b 1,5^{\prime}$ ctcgagcttctcgacgtctga $3^{\prime}$. M13R primer and the synthesized primer were used for a thermocycling reaction to generate the DNA fragment with the $P R-1 b 1$ plasmid as the template. The reaction system was composed of $0.2 \mu \mathrm{g}$ of plasmid DNA, $1 \mu \mathrm{M}$ primers, $0.2 \mathrm{mM}$ dNTPs, $4 \mathrm{mM} \mathrm{MgCl} 2$ buffer, and 0.2 unit of Taq DNA polymerase, and the program consisted of 30 cycles of $94^{\circ} \mathrm{C}$ for $15 \mathrm{~s}, 55^{\circ} \mathrm{C}$ for $15 \mathrm{~s}$, and $72^{\circ} \mathrm{C}$ for $15 \mathrm{~s}$ in an Idaho Technologies thermocycling machine. The product was purified from an agarose gel with the QIAquick gel extraction kit (Qiagen Inc.), and cloned into the pGEM-T-easy vector (Promega Corp.). The sequence of the subclone of PR-1b1 $(8 \mathrm{E} 8 \Delta)$ was determined, and the templates for sense and antisense RNA synthesis were linearized with $X b a \mathrm{I}$ and $X h o \mathrm{I}$. The sense and anti-sense RNA probes for $P R-1 a 1, P R-1 b 1$, $P R-10$, and tomBI- 1 , and the (-)-strand D satRNA labeled with deoxygenin-UTP, were synthesized with the previously described protocol (Xu and Roossinck 2000).

The tomato stems around the second node from mock-, Fny CMV- and Fny CMV/D satRNA-inoculated tomato plants at 9 or $10 \mathrm{dpi}$ were harvested and fixed in phosphate buffer solution containing $4 \%$ formaldehyde, $0.1 \%$ TritonX100 , and $0.1 \%$ Tween- 20 at $4{ }^{\circ} \mathrm{C}$ overnight. The fixed tissues were washed in $0.85 \% \mathrm{NaCl}$ (wt/vol) for $30 \mathrm{~min}$ on ice and dehydrated in serial ethanol saline solutions $(0.85 \% \mathrm{NaCl}$ [wt/vol]) of 50 and $70 \%$ ethanol for $3 \mathrm{~h}$ on ice, $85 \%$ ethanol at $4^{\circ} \mathrm{C}$ overnight, $95 \%$ ethanol at $4^{\circ} \mathrm{C}$ for $4 \mathrm{~h}$, absolute ethanol at $4^{\circ} \mathrm{C}$ for $2 \mathrm{~h}$, and absolute ethanol at room temperature for $2 \mathrm{~h}$. The previously published protocol for low-melting wax infiltration, embedding, section, and RNA in situ hybridization (Xu and Roossinck 2000) was used to detect the localization of D satRNA and the transcripts of $P R-1 a 1, P R$ $1 b 1, P R-10$, and tomBI-1.

\section{ACKNOWLEDGMENTS}

This project was supported by the Samuel Robert Noble Foundation. We thank A. Itaya for the gift of tomato catalase clone, M. J. Harrison and S. Sharma for reviewing the manuscript, and S. J. Roger for technical assistance.

\section{LITERATURE CITED}

Anfoka, G., and Buchenauer, H. 1997. Systemic acquired resistance in tomato against Phytophthora infestans by pre-inoculation with tobacco necrosis virus. Physiol. Mol. Plant Pathology 50:85-101.

Bantignies, B., Séguin, J., Muzac, I., Dédaldéchamp, F., Gulick, P., and Ibrahim, R. 2000. Direct evidence for ribonucleolytic activity of a PR10-like protein from white lupin roots. Plant Mol. Biol. 42:871-881.

Baudouin, E., Charpenteau, M., Roby, D., Marco, Y., Ranjeva, R., and Ranty, B. 1997. Functional expression of a tobacco gene related to the serine hydrolase family Esterase activity towards short-chain dinitrophenyl acylesters. Eur. J. Biochem. 248:700-706.

Bernal, J. J., and García-Arenal, F. 1997. Analysis of the in vitro secondary structure of cucumber mosaic virus satellite RNA. RNA 3:10521067.

Bethke, P. C., and Jones, R. L. 2001. Cell death of barley aleurone protoplasts is mediated by reactive oxygen species. Plant J. 25:19-29.

Breda, C., Sallaud, C., el-Turk, J., Buffard, D., deKosak, I., Esnault, R., and Kondorosi, A. 1996. Defense reactions in Medicago sativa: a gene encoding a class 10 PR protein is expressed in vascular bundles. Mol. Plant-Microbe Interact. 9:713-719.

Bucher, G. L., Rarina, C., Heinlein, M., DeSerio, F., Fred Meins, J., and Iglesias, V. A. 2001. Local expression of enzymatically active class I $\beta$-1,3-glucanase enhances symptoms of TMV infection in tobacco. Plant J. 28:361-369.

Cai, X., Takken, F. L. W., Joosten, M. H. A. J., and Wit, P. J. G. M. D. 2001. Specific recognition of AVR4 and AVR9 results in distinct patterns of hypersensitive cell death in tomato, but similar patterns of defense-related gene expression. Mol. Plant Pathol. 2:77-86.

Chamnongpol, S., Willekens, H., Moeder, W., Langebartels, C., Heinrich Sandermann, J., VanMontagu, M., Inzé, D., and VanCamp, W. 1998. Defense activation and enhanced pathogen tolerance induced by $\mathrm{H}_{2} \mathrm{O}_{2}$ in transgenic tobacco. Proc. Natl. Acad. Sci. U.S.A. 95:5818-5823.

Church, G. M., and Gilbert, W. 1984. Genomic sequencing. Proc. Natl. Acad. Sci. U.S.A. 81:1991-1995.

Cole, A. B., Király, L., Ross, K., and Schoelz, J. E. 2001. Uncoupling resistance from cell death in the hypersensitive response of Nicotiana species to Cauliflower mosaic virus infection. Mol. Plant-Microbe Interact. 14:31-41.

Constabel, C. P., and Brisson, N. 1995. Stigma- and vascular-specific expression of the PR10a gene of potato: a novel pattern of expression of a pathogenesis-related gene. Mol. Plant-Microbe Interact. 8:104-113.

Donofrio, N. M., and Delaney, T. 2001. Abnormal callose response phenotype and hypersusceptibility to Peronospora parasitica in defensecompromised Arabidopsis nim1-1 and salicylate hydroxylase-expressing plants. Mol. Plant-Microbe Interact. 14:439-450.

Du, H., and Klessing, D. F. 1997. Role for salicylic acid in the activation of defense responses in catalase-deficient transgenic tobacco. Mol Plant-Microbe Interact. 10:922-925.

García-Arenal, F., and Palukaitis, P. 1999. Structure and functional relationships of satellite RNAs of cucumber mosaic virus. Pages 37-63 in: Satellites and Defective Viral RNAs. P. K. Vogt and A. O. Jackson, eds. Springer, Berlin.

Grieco, F., Lanave, C., and Gallitelli, D. 1997. Evolutionary dynamics of cucumber mosaic virus satellite RNA during natural epidemics in Italy. Virology 229:166-174.

Hammond-Kosack, K. E., and Jones, J. D. G. 1996. Resistance gene-dependent plant defense responses. Plant Cell 8:1773-1791.

Iglesias, V. A., and Meins, F., Jr. 2000. Movement of plant viruses is delayed in a $3-1,3$-glucanase-deficient mutant showing a reduced plasmodesmatal size exclusion limit and enhanced callose deposition. Plant J. 21:157-166.

Jabs, T. 1999. Reactive oxygen intermediates as mediators of programmed cell death in plants and animals. Biochem. Pharmacol. 57:231-345.

Jordá, C., Alfaro, A., Aranda, M. A., Moriones, E., and García-Arenal, F. 1992. Epidemic of cucumber mosaic virus plus satellite RNA in tomatoes in eastern Spain. Plant Dis. 76:363-366.

Kaper, J. M., and Tousignant, M. E. 1977. Cucumber mosaic virus-associated RNA 5 I. Role of host plant and helper strain in determining amount of associated RNA 5 with virions. Virology 80:186-195.

Karpinski, S., Reynolds, H., Karpinski, B., Wingsle, G., Creissen, G., and Mullineaux, P. 1999. Systemic signaling and acclimation in response to excess excitation energy in Arabidopsis. Science 284:654-657.

Kawai-Yamada, M., Jin, L., Yoshinaga, K., Hirata, A., and Uchimiya, H. 2001. Mammalian Bax-induced plant cell death can be down-regulated by overexpression of Arabidopsis Bax Inhibitor-1 (ATBI-1). Proc. Natl. Acad. Sci. U.S.A. 98:12295-12300.

Király, L., Cole, A. B., Bourque, J. E., and Schoelz, J. E. 1999. Systemic cell death is elicited by the interaction of a single gene in Nicotiana 
clevelandii and gene VI of Cauliflower mosaic virus. Mol. PlantMicrobe Interact. 12:919-925.

Koiwa, H., Kato, H., Nakatsu, T., Oda, J., Yamada, Y., and Sato, F. 1997. Purification and characterization of tobacco pathogenesis-related proteins PR-5d, an antifungal thaumatin-like protein. Plant Cell Physiol. 38:783-791.

Lam, E., Kato, N., and Lawton, M. 2001. Programmed cell death, mitochondria and the plant hypersensitive response. Nature 411:848-853.

Lamb, C., and Dixon, R. A. 1997. The oxidative burst in plant disease resistance. Annu. Rev. Plant Physiol. Plant Mol. Biol. 48:251-275.

Matton, D. P., and Brisson, N. 1989. Cloning, expression, and sequence conservation of pathogenesis-related gene transcripts of potato. Mol. Plant-Microbe Interact. 2:325-331.

McGee, J. D., Hamer, J. E., and Hodges, T. K. 2001. Characterization of a $P R-10$ Pathogenesis-related gene family induced in rice during infection with Magnaporthe grisea. Mol. Plant-Microbe Interact. 14:877886

Mittler, R., Herr, E. H., Orvar, B. L., vanCamp, W., Willekens, H., Inzé, D., and Ellis, B. E. 1999. Transgenic tobacco plants with reduced capability to detoxify reactive oxygen intermediates are hyperresponsive to pathogen infection. Proc. Natl. Acad. Sci. U.S.A. 96:14165-14170.

Moiseyev, G. P., Beintema, J. J., Fedoreyeva, L. I., and Yakovlev, G. I. 1994. High sequence similarity between a ribonuclease from ginseng calluses and fungus-elicited proteins from parsley indicates that intracellular pathogenesis-related proteins are ribonucleases. Planta 193:470-472.

Niderman, T., Genetet, I., Bruyère, T., Gees, R., Stintzi, A., Legrand, M., Fritig, B., and Mösinger, E. 1995. Pathogenesis-related PR-1 proteins are antifungal. Plant Physiol. 108:17-27.

Orozco-Cárdenas, M. L., Narváez-Vásquez, J., and Ryan, C. A. 2001. Hydrogen peroxide acts as a second messenger for the induction of defense genes in tomato plants in response to wounding, systemin, and methyl janmonate. Plant Cell 13:179-191.

Palukaitis, P., Roossinck, M. J., Dietzgen, R. G., and Francki, R. I. B 1992. Cucumber mosaic virus. Pages 281-348 in: Advances in Virus Research. K. Maramorosch, F. A. Murphy, and A. J. Shatkin, eds. Academic Press, San Diego, CA, U.S.A.

Pontier, D., Godiard, L., Marco, Y., and Roby, D. 1994. hsr203J, a tobacco gene whose activation is rapid, highly localized and specific for incompatible plant/pathogen interactions. Plant J. 5:507-521.

Rodríguez-Alvarado, G., and Roossinck, M. J. 1997. Structural analysis of a necrogenic strain of cucumber mosaic cucumovirus satellite RNA in planta. Virology 236:155-166.

Roossinck, M. J., and White, P. S. 1998. Cucumovirus isolation and RNA extraction. Pages 189-196 in: Plant Virology Protocols. G. D. Foster and S. C. Taylor, eds. Humana Press, Totowa, NJ, U.S.A.

Sanchez, P., Zabala, M. D., and Grant, M. 2000. AtBI-1, a plant homologue of Bax Inhibitor-1, suppresses Bax-induced cell death in yeast and is rapidly upregulated during wounding and pathogen challenge. Plant J. 21:393-399.

Scandalios, J. G. 1994. Regulation and properties of plant catalases. In: Cause of Photoxidative Stress and Amelioration of Defense Systems in Plants. C. H. Foyer and P. M. Mullineaux, eds. CRC Press, Boca Raton, FL, U.S.A.

Schmelzer, E., Krüger-Lebus, S., and Hahlbrock, C. 1989. Temporal and spatial patterns of gene expression around sites of attempted fungal infection in parsley leaves. Plant Cell 1:993-1001.
Sleat, D. E., and Palukaitis, P. 1990. Site-directed mutagenesis of a plant viral satellite RNA changes its phenotype from ameliorative to necrogenic. Proc. Natl. Acad. Sci. U.S.A. 87:2946-2950.

Sleat, D. E., Zhang, L., and Palukaitis, P. 1994. Mapping determinants within cucumber mosaic virus and its satellite RNA for the induction of necrosis in tomato plants. Mol. Plant-Microbe Interact. 7:189-195.

Smith, M. M., and McCully, M. E. 1978. Enhancing aniline blue fluorescent staining of cell wall structures. Stain Technol. 53:79-85.

Sticher, L., Mauch-Mani, B., and Métraux, J. P. 1997. Systemic acquired resistance. Pages 235-270 in: Annual Review of Phytopathology. R. K. Webster, G. Shaner, and N. K. VanAlfen, eds. Annual Reviews Inc., Palo Alto, CA, U.S.A.

Takahashi, H., Chen, Z., Du, H., Liu, Y., and Klessig, D. F. 1997. Development of necrosis and activation of disease resistance in transgenic tobacco plants with severely reduced catalase levels. Plant J. 11:9931005 .

Takeda, S., Sato, F., Ida, K., and Yamada, Y. 1991. Nucleotide sequence of a cDNA for osmotin-like protein from cultured tobacco cells. Plant Physiol. 97:844-846.

Taliansky, M. E., Ryabov, E. V., Robinson, D. J., and Palukaitis, P. 1998. Tomato cell death mediated by complementary plant viral satellite RNA sequences. Mol. Plant-Microbe Interact. 11:1214-1222.

Thordal-Christensen, H., Zhang, Z., Wei, Y., and Collinge, D. B. 1997. Subcellular localization of $\mathrm{H}_{2} \mathrm{O}_{2}$ in plants. $\mathrm{H}_{2} \mathrm{O}_{2}$ accumulation in papillae and hypersensitive response during the barley-powdery mildew interaction. Plant J. 11:1187-1194.

Tornero, P., Conejero, V., and Vera, P. 1994. A gene encoding a novel isoform of the PR-1 protein family from tomato is induced upon viroid infection. Mol. Gen. Genet. 243:47-53.

Tornero, P., Gadea, J., Conejero, V., and Vera, P. 1997. Two PR-1 genes from tomato are differentially regulated and reveal a novel mode of expression for a pathogenesis-related gene during the hypersensitive response and development. Mol. Plant-Microbe Interact. 10:624-634.

Tornero, P., Rodrigo, I., Conejero, V., and Vera, P. 1993. Nucleotide sequence of a cDNA encoding a pathogenesis-related protein, P1-p14, from tomato (Lycopersicon esculentum). Plant Physiol. 102:325.

Tronchet, M., Ranty, B., Marco, Y., and Roby, D. 2001. HSR203 antisense suppression in tobacco accelerates development of hypersensitive cell death. Plant J. 27:115-127.

vanKan, J. A. L., Joosten, M. H. A. J., Wagemakers, C. A. M., vandenBerg-Velthuis, G. C. M., and deWit, P. J. G. M. 1992. Differential accumulation of mRNAs encoding extracellular and intracellular PR proteins in tomato induced by virulent and avirulent races of Cladosporium fulvum. Plant Mol. Biol. 20:513-527.

vanLoon, L. C. 1999. Occurrence and properties of plant pathogenesisrelated proteins. Pages 1-47 in: Pathogenesis-Related Proteins in Plants. S. K. Datta and S. Muthukrishnan, eds. CRC Press, Boca Raton, FL, U.S.A.

Warner, S. A. J., Scott, R., and Draper, J. 1993. Isolation of an asparagus intracellular $P R$ gene $(A o P R l)$ wound-responsive promoter by the inverse polymerase chain reaction and its characterization in transgenic tobacco. Plant J. 3:191-201.

Wu, G., and Shah, D. M. 1995. Isolation and characterization of a potato catalase cDNA (GenBank U27082). Plant Gene Register PGR95-037.

$\mathrm{Xu}, \mathrm{P}$. , and Roossinck, M. J. 2000. Cucumber mosaic virus D satellite RNA-induced programmed cell death in tomato. Plant Cell 12:10791092 . 